\title{
Estimation of Heterosis Combining and Ability in Faba Bean (Vicia faba L.) by Line X Tester Technique
}

\author{
Mohammed S. M. Abd EL-ATY1, Mahmoud A. EL-Hity ${ }^{1}$, Tharwat M. Abo Sen² and Ibrahim A. E. Abd \\ EL-Rahaman ${ }^{2}$ \\ 1. Agron. Dept., Fac. of Agric., Kafer EL-Sheikh Univ., Egypt. \\ 2. Food Legumes Program, Field Crops Research Institute, ARC, Egypt. \\ Corresponding author: Ibrahim.a.elmamoun@gmail.com
}

\begin{abstract}
The present study was conducted at Sakha Research Station during 2014/2015 and 2015/2016 growing seasons. Line x Tester analysis was used, five lines and four testers were crossed in all possible cross combination according to factorial mating design producing twenty hybrids of Faba Bean in the first season. All genetic materials were tested under two sowing dates, i.e. October 20 (early date) and November 20 (late date) each in one experiment arranged in a randomized complete block design with three replications in the second season. Results revealed highly significant variations within parents and $F_{1}$ genotypes indicating a wide genetic variability for the studied characters and the possibility of genetic improvement using such genetic pools of faba bean. Regarding yield and its components traits, the most crosses exhibited significant positive heterosis values relative to better parent for total dry seed yield, three, six and four crosses exhibited significant positive heterotic effects relative to better parent for number of seeds/plant, seed yield/plant and 100-seed weight respectively, under the two sowing dates. Both general (GCA) and specific (SCA) combining ability were significant for the most studied characters revealing the important role of both additive and dominant components in the inheritance of the studied characters. The parental genotype (Giza716) was a good combiner for seed yield/plant and100-seed weight under the two sowing dates. Several crosses exhibited significantly positive SCA effects for the most studied characters especially the crosses (Sakha 4 x Qahera 4, Cross 957 x Giza 843 and Giza 716 x Qahera 4) and the crosses (Sakha1 x Misr 1, Sakha 4 x Misr 1 and Giza 40 x Giza 843) which exhibited highly significant and positive SCA effects for seed yield/plant and 100-seed weight respectively under the two sowing dates. Heritability in broad sense estimates $\left(\mathrm{H}_{\mathbf{b}} \%\right)$ were higher than their corresponding of narrow sense heritability $\left(\mathrm{H}_{\mathbf{n}} \%\right)$. The estimates of narrow sense heritability ranged were $(37.7-40.4 \%),(33.7-46.8 \%)$ and (45.5-48.3\%) for number of seeds/plant, seed yield/plant and 100-seed weight, respectively under the two sowing dates.
\end{abstract}

Keywords: Combining ability, heritability, heterosis and Faba bean.

\section{Introduction}

Faba bean (Vicia faba L.) is one of the most important grain legumes in prone regions of North and East Africa, especially in Egypt. It plays an important role in world agriculture, owing to its high protein content, ability to fix atmospheric nitrogen, capacity to grow and yield well on marginal lands. Faba bean is a self-pollinating plant with significant levels of outcross and inter-cross, ranging from 20 to $80 \%$ (Suso and Moreno, 1999) depending on genotype and environmental effects. The genetic improvement of crop desired traits depends on the nature and magnitude of genetic variability and interactions involved in the inheritance of these traits which can be estimated using line $\mathrm{x}$ tester cross technique. This technique may also result in the production of new genetic combinations whose performance, negatively or positively, may exceed that of the parents, a phenomenon known as heterosis.

Exploitation of heterosis could pay off improving yield potential and its components in faba beans, where superiority of hybrids over the mid and/or better parents for seed yield is associated with manifestation of heterotic effects in important yield components, i.e., number of branches/plant, number of pods and seeds/plant and seed index.

The Combining ability helps the breeder to identify the best combiners, which may be hybridized either to exploit heterosis or to build up the favorable fixable genes (El-Harty 1999, Ghareeb 2000 and Attia et al., 2001). Bond (1967) used the relative importance of GCA to SCA effects as criteria for selection of parents for hybrid varieties.

The objectives of the present study were to (a) estimate potentiality of nine faba bean parental genotypes and their crosses, (b) the heterotic effects based on better parent(c) the importance of these materials in a breeding program by evaluating their general and specific combining ability effects.

\section{Materials and Methods}

The present investigation was carried out at Sakha Agricultural Research station. Agriculture 
Research center, Egypt, during the two growing seasons 2014/2015 and 2015/2016

\section{Genetic materials:}

The genetic materials used in this study were four, male testers namely; Misr 1(T1), L 73 (T2), Giza 843 (T3) and Qahera 4 (T4) as well as five entries of faba bean as female parents namely; Sakha 1(L1), Sakha 4 (L2), Giza 40 (L2), Cross 957 (L4) and Giza 716 (L5).

In 2014/2015 season the four male testers and the five female parents were crossed according to line $\mathrm{x}$ tester design to produce $20 \mathrm{~F}_{1}$ crosses as out lined by Kempthorne (1957).

In 2015/2016 season, two field experiments were conducted in two sowing dates, early sowing in 20 October (S1) and late sowing in 20 November (S2).

The experimental design was randomized complete block design with three replications. Each replicate contained $20 \mathrm{~F}_{1}$ and nine parents, each entry was grown in a single row 3 meter long and $0.60 \mathrm{~m}$ apart with single seeded hills of $20 \mathrm{~cm}$ apart. Ten guarded plants were randomly selected for the different measurements. The studied characters were recorded as follows: days to maturity (DM), plant height $(\mathrm{PH}) \mathrm{cm}$, number of branches/plant (NBP), number of pods/plant (NPP), number of seeds/plant (NSP), seed yield/plant (SY) g and 100-seed weight (100-SW) g.

Statistical analysis were performed for each experiment. The combining ability analysis was done using the line $\mathrm{x}$ testers procedure as suggested by Cochran and Cox (1957) and Kempthorne (1957). Heterosis was calculated as the percentage of increase as decrease relative to better parent. Significance of heterosis was tested according to Wynne et al., (1970). Estimates of heritability in both broad and narrow sense were calculated according to Mather (1949).

\section{Results and Discussion}

\section{Analysis of variance and mean performance: Analysis of variance}

The analysis of variance for each experiment for all the studied traits are presented in (Table 1). Highly and/or significant mean squares of entries, parents, crosses, parent's vs crosses lines (L), tester (T) and (L) $\mathrm{x}(\mathrm{T})$ were found for all studied characters under the first and second sowing dates, except days to maturity under the second sowing date and number of branches/plant under the two sowing dates.

The present findings revealed that, sufficient amount of variability was present for carrying out various analyses in present investigation

\section{Mean performance of parents.}

The mean performances of the tested parental genotypes for each planting date are presented in
(Table 2). The earliest days to maturity were recorded 145.88 and 123.6 days for parent (L 73) under the two sowing dates. Regarding plant height, the two parents Giza 716 and Giza 843 had the tallest plants $(120.70-101.21 \mathrm{~cm})$ and $(120.70-97.17 \mathrm{~cm})$, under the two sowing dates respectively, whereas the shortest plants belonged to Sakha1 which recorded $(104.50-88.10 \mathrm{~cm})$ with an average mean values of 114.80 and $94.34 \mathrm{~cm}$ under the two sowing dates. The two parental genotypes Sakha 4 and Giza 843 exhibited the highest number of branches/plant 4.31 - 3.11 and $4.18-3.19$ ) under the two sowing dates respectively, whereas Cross 957 recorded the lowest value for that character under the two sowing dates. However, Giza 40 had the highest number of pods and seeds/plant $(24.10-19.57)$ and $(78.12-58.04)$ under the two sowing dates respectively, whereas Qahera 4 had the lowest number of pods and seeds/plant under the two sowing dates. On the other hand, Giza 843 had the highest seed yield/plant $(63.97$ - $36.23 \mathrm{~g})$ compared to the other eight parents. The two parental genotypes Cross 957 and Sakha 4 exhibited the highest significantly 100 -seed weight $(90.13-80.83$ and $83.43-73.13) \mathrm{g}$ under the two sowing dates.

\section{Mean Performance of $F_{1}$ (hybrids)}

The mean performance of the twenty crosses at each planting date are parental in (Table 2). The earliest days to maturity recorded $145.00-126.48$ days for $\mathrm{F}_{1}$ (Giza $40 \mathrm{x}$ Misr 1) and maximum days to maturity was recorded $160.00-139.73$ days for $F_{1}$ (Cros 957 x Giza 843), with an average mean value of $153.60-134.42$ days under the two sowing dates respectively. Regarding plant height, the Cross $957 \mathrm{x}$ Giza 843 had the tallest plants (143.03 $-107.96 \mathrm{~cm})$ under the two sowing dates respectively, whereas the shortest plants belonged to cross Sakha 4 x Misr 1 which recorded $(110.50 \mathrm{~cm})$ under the first sowing date, while, in the second sowing date the shortest plants belonged to Sakha 1 x L 73 which recorded $(87.86 \mathrm{~cm})$ with an average mean value of $(122.84$ and $99.19 \mathrm{~cm})$ under the two sowing dates respectively. The number of branches/plant varied between 3.39 - 3.12 for (Cross 957 x Giza 843) to $5.03-3.51$ for (Sakha $4 \times$ Qahera 4) branches with an average of $4.16-3.51$ branches under the two sowing dates respectively. The number of pods/plant ranged from 16.40 - 12.63 for (Giza 40 x Giza 843) to $26.50-20.18$ for (G716 x Qahera 4) pods, with an average value $20.97-14.95$ pods under the two sowing dates respectively. The number of seeds/plant ranged from 64.11(Sakha 4 x Misr 1) to 95.06 (Giza $40 \times$ Qahera 4) under the first sowing date, while in the second sowing date, number of seeds/plant ranged from 40.46 for (Giza $40 \times$ Qahera 4) to 56.34 for (Cross 957 x Giza 843) with an average value 82.30 - 50.66 seed under the two sowing dates respectively. 


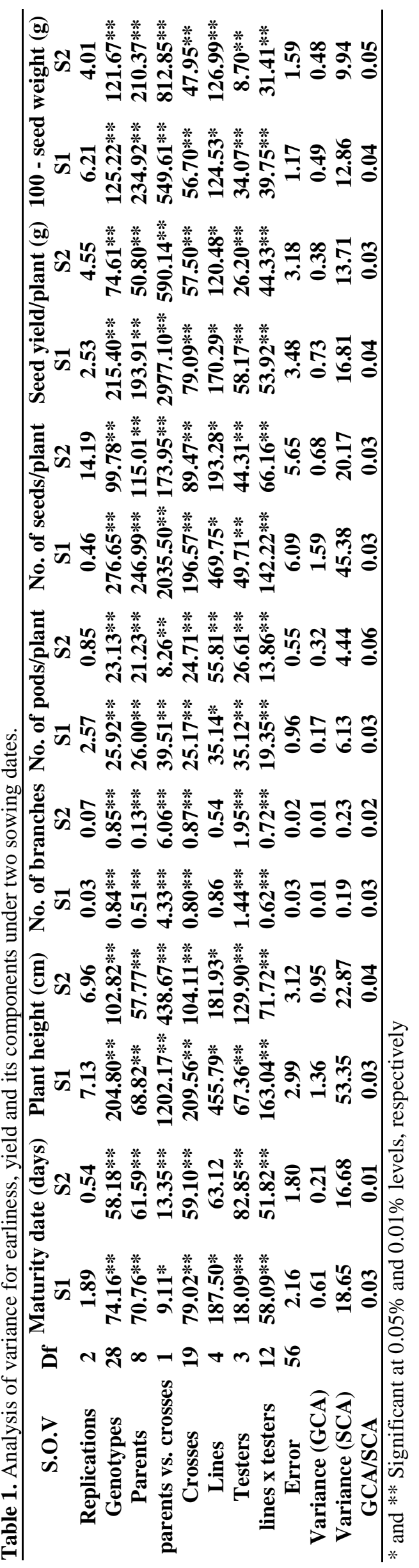




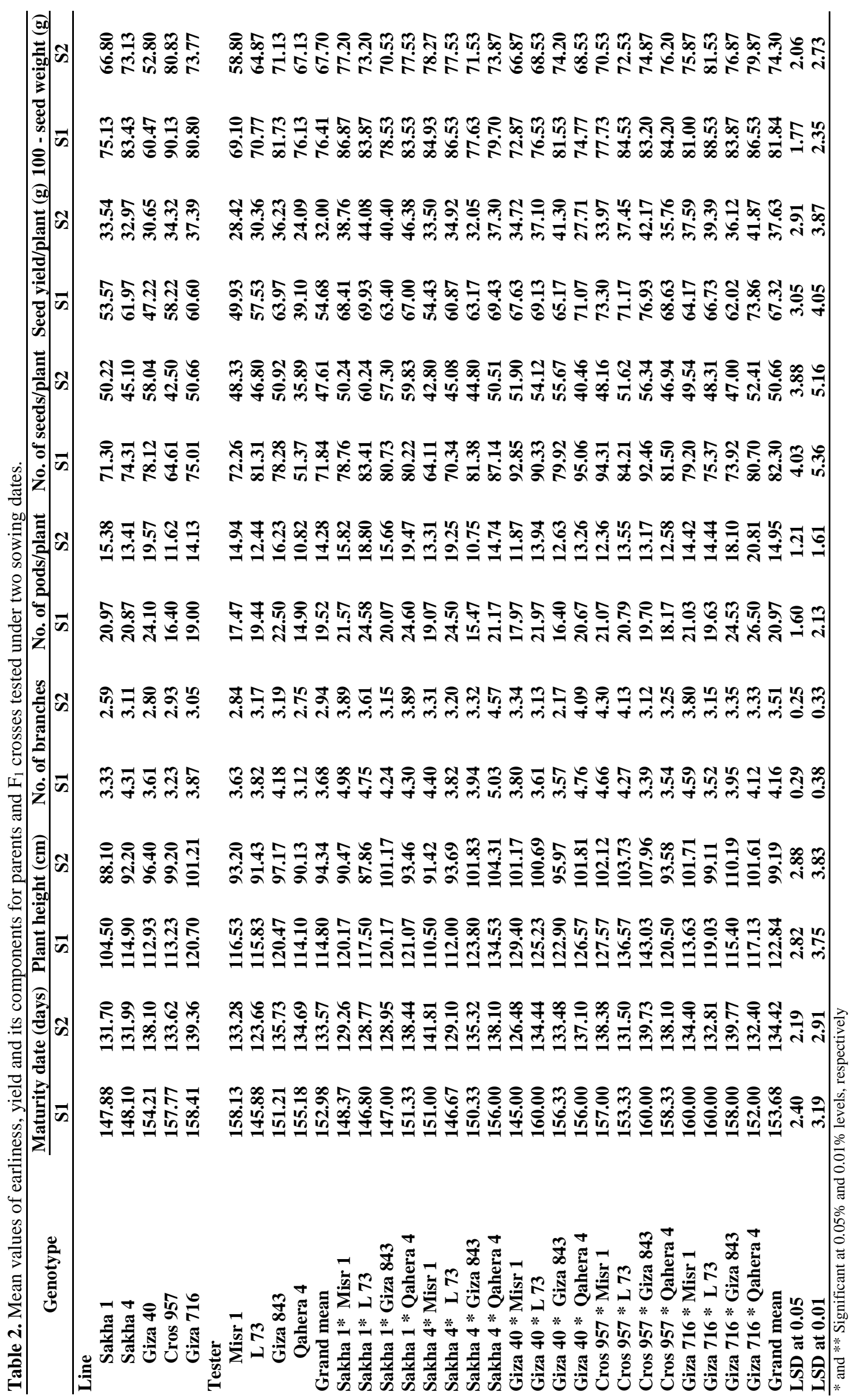


The seed yield/plant ( $\mathrm{g}$ ) was recorded highest for $\mathrm{F}_{1} 76.73 \mathrm{~g}$ (Cross 957x Giza 843) and 54.43 g (Sakha $4 \mathrm{x}$ Misr 1) recorded the lowest seed yield/Plant under the first sowing date, while in the second sowing date, the seed yield/plant $(\mathrm{g})$ was recorded highest for $F_{1} 46.38 \mathrm{~g}$ (Sakha $1 \mathrm{x}$ Qahera 4) and 27.71g (Giza $40 \times$ Qahera 4) recorded the lowest seed yield/with an average of $67.32-37.63 \mathrm{~g}$ under the two sowing dates respectively. The average mean values of 100 seed weight are $81.84-74.30 \mathrm{~g}$ ranged from 88.53 - $81.53 \mathrm{~g}$ (Giza 716 x L 73) to 72.87 $66.87 \mathrm{~g}$ (Giza $40 \mathrm{x}$ Misr 1) under the two sowing dates respectively.

\section{Combining ability analysis for GCA and SCA effects: -}

The analysis of variance for combining ability in each sowing date for all the studied traits are presented in (Table 1). The mean squares for general and specific combining ability were found for all the studied traits, indicating the additive and nonadditive components were important in the inheritance of these traits.

\section{Combining ability analysis for GCA and SCA effects.}

The estimates of general combining ability (GCA) effects of lines and testers are presented in (Table 3) and specific combining ability (SCA) effects of hybrids for different characters are presented in (Table 4).

\section{General combining ability (GCA) effects.}

Among lines and testers only one genotype Sakha 1 showed highly significant and negative GCA effects for maturity date under the two sowing dates. The parent Sakha 1 appeared as a good general combiner for early mature. For plant height, the GCA effects of the parents (lines and testers) ranged from 6.54 (Giza716) to 9.08 (Cross 957) and -5.96 (Sakha 1) to 4.23 (Giza 843) under the first and second sowing dates respectively. Among the lines and testers, Sakha 1, Sakha 4 and Misel showed positive highly significant GCA effects under the two sowing dates. These parents appeared as a good general combiner for plant height. Among the lines and testers, Sakha 1 and Qahera 4 showed positive highly significant GCA effects for number of branches and pods/plant under the two sowing dates. These parents appeared as a good general combiner for these traits. For number of seeds/plant, the parents Giza 40, Cross 957 and Qahera 4 showed positive highly significant GCA effects under the first sowing date, while in the second sowing date the parents, Sakha 1 Giza 843 showed positive highly significant GCA effects. Therefore, the superior faba bean parents in their GCA effects (significant and positive) indicated that these parents are favorable for inclusion in the production of synthetic cultivars. In the same frame, the parental genotype (Giza716) was a good combiner for seed yield/plant and100-seed weight over the other parents under the two sowing dates. The detection of the combining ability of the parental genotypes provides better information not only for selecting the parents for hybridization (or building synthetic cultivars) but also in choosing the pro/breeding scheme. Similar results were obtained by El-Hady (1988), Attia (1998) Abdalla et al., (1999), Darwish et al., (2001), Abd El-Mohsen (2004), Darwish et al., (2005), Attia and Salem (2006) and Farag (2007).

\section{Specific combining ability (SCA) effects.}

The estimates of specific combining ability (SCA) effects were presented in (Table 4). Four crosses (Sakha 1 x Giza 843, Giza 40 x Misr 1, Cross 957 x L 73 and Giza 716 x Qahera 4), three crosses (Sakha 4 x Qahera 4, Giza 843 x Misr 1 and Cross 957 x L 73), three crosses (Sakha 4 x Qahera 4, Giza 40 x Qahera 4 and Cross 957 x Misr 1), three crosses (Sakha 4 x L 73, Giza 716 x Giza 843 and Giza 716 x Qahera 4), two crosses (Sakha 4 x Qahera 4 and Cross 957 x Giza 843), three crosses (Sakha 4 x Qahera 4, Cross 957 x Giza 843 and Giza 716 x Qahera 4) and three crosses (Sakha 1 x Misr 1, Sakha 4 x Misr 1 and Giza 40 x Giza 843), exhibited highly significant(SCA) effects for maturity date, plant height, number of branches, pods and seeds/plant, seed yield/plant and 100-seed weight, respectively under the two sowing dates. From the breeding point of view, parents characterized by good general combining ability for yield and its components along with considerable heterosis and high estimates of SCA effects are obviously essential. This conclusion are in agreement with those obtained by El-Hady $\boldsymbol{e t}$ al., (1998), Attia (1998), Attia et al., (2002) and ElHady et al., (2006).

\section{Heterotic effects}

Estimates of heterosis relative better parent for all studied traits are presented in (Table 5). in this direction, two crosses (Giza $40 \mathrm{x}$ Misr 1 and Giza 716 x Qahera 4) significantly matured earlier than their better parent with negative heterosis values under the two sowing dates. In respect to vegetative traits, four, five and four crosses exhibited significant positive heterotic effects relative to better parent for plant height (Cross 957 x Giza 843, Cross 957 x L 73, Giza 40 x Misr 1 and Sakha 4 x Qahera 4 ), number of branches/plant (Sakha 1 x Misr 1 , Giza 40 x Qahera 4, Sakha 1 x Qahera 4, Cross 957 x Misr 1 and Sakha 4 x Qahera 4 ), and number of pod/plant (Giza 716 x Qahera 4, Sakha 4 x L 73, Sakha 1 x Qahera 4 and Sakha 1 x L 73 ), respectively, under the two sowing dates. 


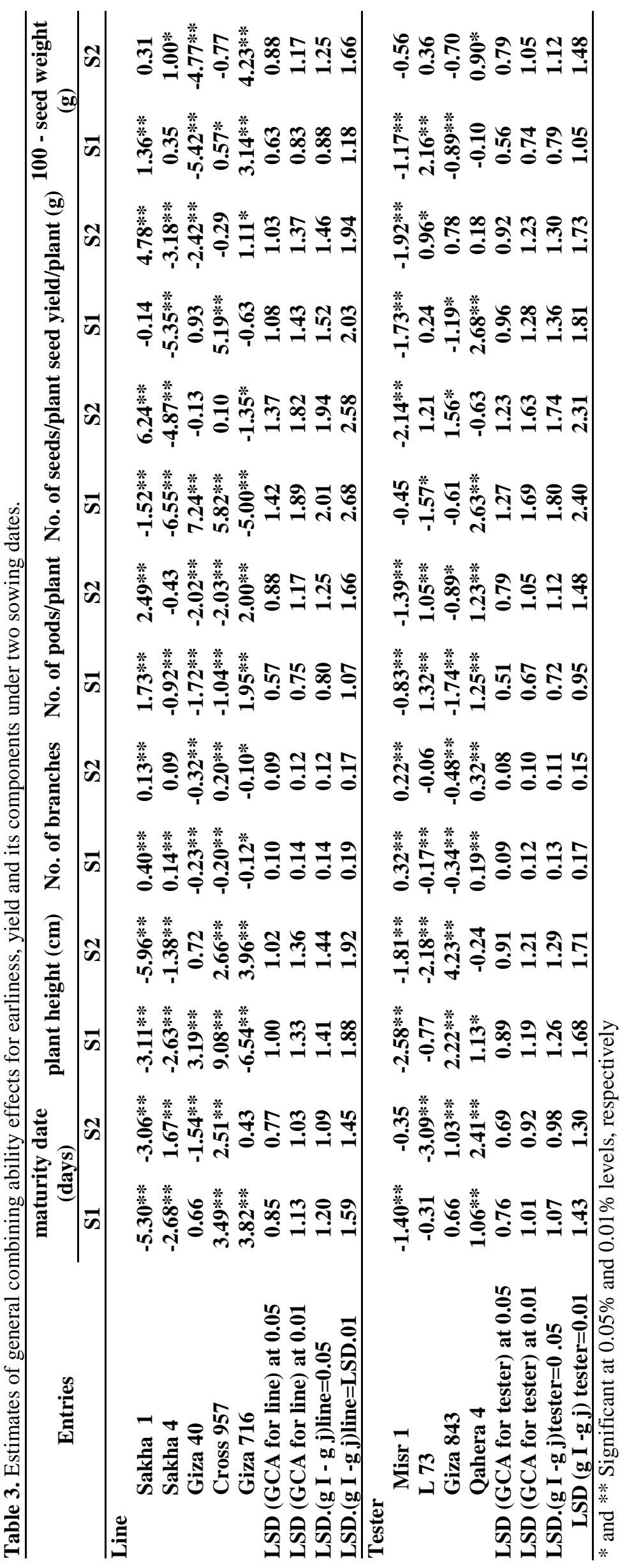




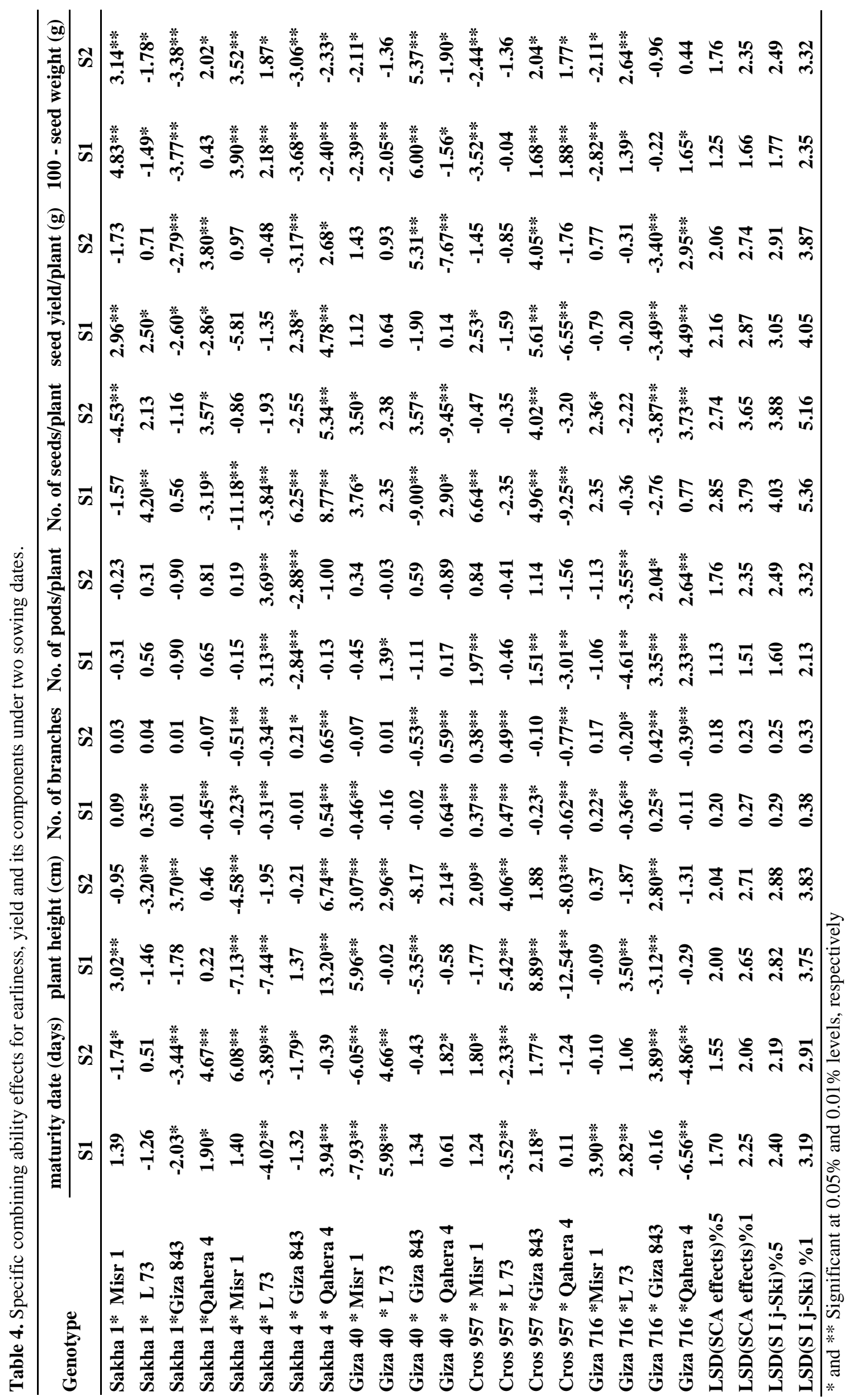




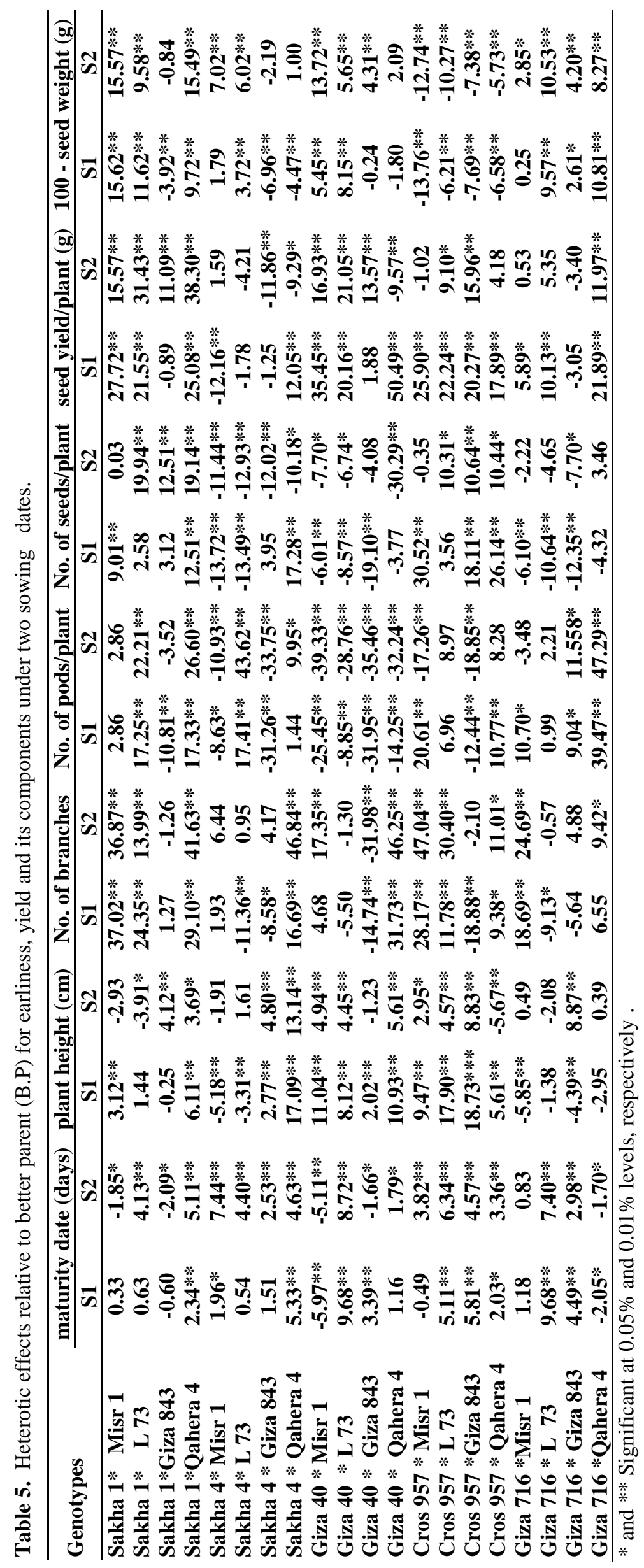


Regarding yield and its components traits, the most crosses exhibited significant positive heterosis values for seed yield. Three, six and four crosses exhibited significant positive heterotic effects relative to better parent for number of seeds/plant (Cross $957 \mathrm{x}$ Qahera 4, Cross 957 x Giza 843 and Sakha 1 x Qahera 4), seed yield/plant (Giza 40 x Misr 1, Sakha 1 x Misr 1, Sakha 1 x L 73, Sakha 1 x Qahera 4, Cross 957 x Giza 843 and Giza 716 x Qahera 4) and 100-seed weight (Sakha 1 x Misr 1, Sakha 1 x L 73, Giza 40 x Misr 1 and Giza 716 x Qahera 4) respectively, under the two sowing dates. In general, these results indicated that most crosses were significantly earlier and higher yielding than their better parent, suggesting the important role of nonadditive gene action in the inheritance of studied traits. Pronounced and favorable heterosis values relative to better parents have been obtained by several investigators for faba bean traits which varied according to the cross combinations and traits (Stelling, 1997; Schill et al., 1998; Abdelmula et al., 1999; Bond and Crofton, 1999; Filippetti et al., 1999; Abdalla et al., 2001; Attia et al., 2002; Ahmed and Kambal 2005; Darwish et al., 2005; Attia and Salem, 2006; El Hady et al., 2006; Kunkaew et al., 2006; El-Hady et al., 2007; Gasim and Link, 2007; Tantawy et al., 2007; Link et al., 2008; Soliman et al., 2008; Alghamdi, 2009 and Abdalla et al., (2011)

Gene action.

Estimates of all types of gene action for all studied traits are presented in (Table 6). The results indicated that the magnitude of additive genetic variance $\left(\sigma^{2} \mathrm{~A}\right)$ were positive and lower than those of non-additive $\left(\sigma^{2} \mathrm{D}\right)$ one for all of studied traits. This finding could be verified by the ratio $\left(\sigma^{2} \mathrm{D} / \sigma^{2} \mathrm{~A}\right)^{1 / 2}$ which was higher than one, indicating that non additive gene action played a major role in the inheritance of these studied traits. Similar findings were reported by El-Hady et al., (1998), Salama and Salem (2001) and Toker (2009).

\section{Estimates of heritability}

The results in (Table 6) showed that broad sense heritability estimates $\left(\mathrm{H}_{\mathrm{b}} \%\right)$ were higher than their corresponding of narrow sense heritability $\left(\mathrm{H}_{\mathbf{n}} \%\right)$.

The estimates of narrow sense heritability were (38.90 - 25.34\%) for maturity date, also heritability ranged were $(34.13$ - 48.98), (41.21 - 37.94) and (39.72 -61.89) \% for plant height, number of branches and pods/plant respectively under the two sowing dates.

Respecting to yield and yield components, the estimates of narrow sense heritability ranged from (37.66 to 40.35$)$, (33.72 to 46.82) and (48.36 to $45.51) \%$ for number of seeds/plant, seed yield/plant and 100-seed weight, respectively under the two sowing dates. These findings may be indicated that the possibility of increasing seed yield through selection for 100-seed weight and considered as one of important yield component. similar findings were reported by Abdalla et al., (1999), Mansour et al., (2001), Salama and Salem (2001), Darwish et al., (2005), El-Hady et al., (2007), Abo Mostafa et al., (2009), Toker (2009) and Ashrei et al., (2013).

Table 6. Estimates of mean performance $(\dot{\mathbf{x}})$, experimental error $\left(\sigma^{2} \mathrm{e}\right)$, additive $\left(\sigma^{2} \mathrm{a}\right)$ and dominance $\left(\sigma^{2} \mathrm{~d}\right)$, broad $\left(\mathrm{H}_{\mathrm{b}}\right)$ and narrow $\left(\mathrm{H}_{\mathrm{n}}\right)$ sense heritability for all studied traits under the two sowing dates of all tested genotypes

\begin{tabular}{|c|c|c|c|c|c|c|c|c|c|c|c|c|c|c|}
\hline \multirow{2}{*}{ 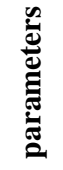 } & \multicolumn{2}{|c|}{$\begin{array}{l}\text { Maturity date } \\
\text { (days) }\end{array}$} & \multicolumn{2}{|c|}{ Plant height $(\mathbf{c m})$} & \multicolumn{2}{|c|}{ No. of branches } & \multicolumn{4}{|c|}{ No. of pods/plant No. of seeds/plant } & \multicolumn{2}{|c|}{$\begin{array}{c}\text { Seed yield/plant } \\
(\mathrm{g})\end{array}$} & \multicolumn{2}{|c|}{$\begin{array}{l}100 \text { - seed } \\
\text { weight }(g)\end{array}$} \\
\hline & S1 & S2 & S1 & S2 & S1 & $\mathbf{S 2}$ & S1 & S2 & S1 & S2 & S1 & S2 & $\mathbf{S 1}$ & S2 \\
\hline$\dot{\mathbf{x}}$ & 153.4 & 134. & 120.34 & 97. & & & & & & & & & & \\
\hline$\sigma^{2} e$ & 2.16 & 1.80 & & & 0.03 & & & 0.55 & 09 & & 3.48 & 3. & 1.17 & 1.59 \\
\hline$\sigma^{2} \mathbf{a}$ & 1.22 & 0.42 & 2.72 & 1.89 & 0.01 & 0.01 & 0.34 & 0.63 & 3.17 & 1.36 & 1.47 & 0.77 & 0.99 & 0.97 \\
\hline$\sigma^{2} d$ & 18.65 & 16.68 & 53.35 & 22.87 & 0.19 & 0.2 & 6.13 & 4.44 & 45.38 & 20. & 16.81 & 13.71 & 12.86 & 9.94 \\
\hline$H_{n}$ & 38.90 & 25.34 & 34.13 & 48.98 & 41.21 & 37.94 & 39.72 & 61.89 & 40.35 & 37.66 & 46.82 & 33.72 & 45.51 & 48.36 \\
\hline $\mathbf{H}_{b}$ & 93.67 & 92.74 & 96.51 & 93.88 & 91.89 & 94.33 & 91.81 & 95.78 & 92.94 & 86.36 & 90.87 & 87.52 & 95.44 & 92.90 \\
\hline
\end{tabular}

\section{References}

Abd El-Mohsen, M. I. (2004). Heterosis and combining ability in faba bean for some quantitative characters. Egypt. J. Plant Breed., 8: 161-171.

Abdalla, M. M. F., M. M. Shafik, S. M. Attia and H. A. Ghannam( 2011). Investigations on faba beans, Vicia faba L. genetic analysis of earliness characters and yield components. Egypt. J. Plant Breed., 15 (3): $71-83$.
Abdalla, M. M. F, D. S. Darwish, M. M. El- Hady and E. H. El-Harty (1999). Investigations on faba beans, (Vicia faba, L.) Diallel crossed materials grown under cages. Proceed. First P1. Breed. Conf., Egypt. J. Plant Breed., 3: 213 -229.

Abdalla, M. M. F, D. S. Darwish, M. M. El-Hady and E. H. El-Harty (2001). Investigations on faba bean (Vicia faba L.) $16-\mathrm{F}_{1}$ and $\mathrm{F}_{2}$ diallele hybrids with reciprocals among five parents. Egypt. J. Plant Breed., 5: 155-179. 
Abdelmula, A. A., W. Link, E. Kittlitz and D. Von Stelling (1999). Heterosis and inheritance of drought tolerance in faba bean Vicia faba L. Plant Breed., 118: 485-490.

Abo Mostafa, R. A. I., W. M. El-Rodeny and A. M. Hassanein (2009). Generation mean analysis of earliness and chocolate spot disease resistance and quantitative variation in the storage proteins of three Vicia faba L. Crosses J. Agric. Sci., Mansoura Univ., 34 (2): 925-943.

Ahmed, M. I. and A. E. Kambal (2005). Heterosis and inbreeding depression in faba bean (Vicia faba L.). J. Agric. Sci., 13 (2): 224-232.

Alghamdi, S. S. (2009). Heterosis and combining ability in a diallele cross of eight faba bean (Vicia faba L.) genotypes. Asian J. Crop Sci., 1 (2): 6676.

Ashrei, A. A. M., Z. E. Ghareeb, Kh. M. M. Ymani, R. A. M. Abd Elrahman and A. AlGarhy (2013). Statistical and genetical analysis of yield and some related components in faba bean. Egypt J. Plant Breed., 17 (5): 57-67.

Attia S. M. (1998). Performance of some faba bean genotypes and hybrids and reaction to Orobanche. Ph. D. Thesis, Fac. Agric., Cairo Univ., Egypt.

Attia, S. M. and M. M. Salem (2006). Analysis of yield and its components using diallel matings among five parents of faba bean. Egypt. J. Plant Breed., 10 (1): 1-12.

Attia, S. M., M. S. Zakia, M. Ezzat, A. M. A. Rizk and K. A. Aly (2002). Heterosis, combining ability and gene action in crosses among six faba bean genotypes, Egypt. J. Plant Breed., 6:191210.

Attia, S. M., F. H. Shalaby, Z. S. El-Sayad and M. M. El-Hady (2001). Heterosis, inbreeding depression and combining ability in a diallel cross of five faba bean genotypes. Annals of Agric. Sc., Moshtohor. 39 (1): 53-64.

Bond, D. A. (1967). Combining ability of winter beans (Vicia faba L.) inbreeds. J. Agric. Sci. Camb., 68: 179-185.

Bond, D. A. and G. R. A. Crofton (1999). History of winter beans (Vicia faba) in the Uk. J. Res. Agric. Soc. Engl., 160: 200-209.

Cochran, W. G. and G. M. Cox (1957). Experimental Designs. Asia Publication House, Bombay.

Darwish, D. S., M. M. F. Abdalla, M. M. El-Hady and S. El-Emam (2005). Investigations on faba beans, Vicia faba L. 19-Diallel and triallel matings using five parents. Proc. $4^{\text {th }}$ Plant Breed. Conf. March 5 (Suez Kanal University), Egypt J. Plant Breed., 9 (1): 197-208.

Darwish, D. S., M. M. F. Abdalla and S. R. E. Abo- Hegazy (2001). Investigations on faba beans, Vicia faba L. 17-Polycrosses, open crosses and inbreds. Proc. $2^{\text {nd }}$ Plant Breed. Confr. Oct. 2 (Assuit Univ.,): 375-389.
EI-Hady, M. M., M. A. Omar, S. M. Nasr, K. A. Ali and M. S. Essa (1998). Gene action on seed yield and some yield components in $F_{1}$ and $F_{2}$ crosses among five faba bean (Vicia faba L.) genotypes. Bull. Fac. Agric. Univ. Cairo. 49: 369388.

El-Hady, M. M., S. M. A. Olaa, A. M. El-Galaly and M. M. Salem (2006). Heterosis and combining ability analysis of some faba bean genotypes. J. Agric. Res. Tanta Univ., 32: 134148

El-Hady, M. M., A. M. Rizk, M. M. Omran, and S. B. Ragheb (2007). Genetic behavior of some faba bean (Vicia faba L.) genotypes and their crosses. Ann. Agric. Sci. Moshtohor, 45: 49-60.

El-Hady, M. M., M. A. Omar, S. M. Nasr, S. A. Mahmoud and M. K. El-Waraky (1998). Performance of some faba bean genotypes along with $F_{1}$ and $F_{2}$ generations. Annals of Agric. Sci., Moshtohor. 36 (2): 729-743.

El-Hady, M. M. (1988). Diallel analysis of resistance to chocolate spot disease (Botrytis faba esard.) and other agronomic traits in faba bean (Vicia faba L.). Ph.D. Theses Fac. Agric., Cairo, University.

El-Harty, E. H. S. A., (1999). Performance of hybrids among five faba bean parents. M.Sc. Thesis Fac. Agric, Cairo Univ., Egypt.

Farag, S. T. (2007). Relative importance of genetic variance for improving broad bean (Vicia faba L.) Egypt. J. Plant Breed., 11 (1): 301-315.

Filippetti, A., G. H. Azadegano and C. Pace De (1999). Breeding strategies for seed protein content and trypsin inhibitors inferred from combining ability and heterosis in test crosses of Vicia faba. Plant Breed., 118: 411-416.

Gasim, S., and W. Link (2007). Agronomic performance and the effect of self-fertilization on German winter faba. J. Central Eur. Agric., 8: 121-127.

Ghareeb, Z. E. (2000). Genetical studies on faba bean. M. Sc. Thesis. Gen. Dep., Fac. Agric. Zagazig University, Egypt.

Kempthorne, O. (1957). An Introduction to Genetic Studies. John Willey and SonsInc., New York, USA.

Kunkaew, W., S. Julsrigival, C. Senthong and D. Karladee (2006). Estimation of heterosis and combining ability in azukibean under highland growing condition in Thailand. Chiang Mai. Univ. J. 5: 163-168.

Link, W., C. Balko and F. L. Stoddard (2008). Winter hardiness in faba bean: Physiology and breeding. Field Crops Res., 115: 287-296.

Mansour, S. H., S. M. Attia, M. M. Salem and M. M. El-Hady (2001). Genetic analysis of shedding and some yield characters in faba bean. J. Agric. Sci. Mansoura University, 26 (4): 1875-1887.

Mather, K. (1949). Biometrical genetics. Dover Publications. Inc., London. 
Salama, S. M. and M. M. Salem (2001). Genetic analysis and combining ability over sowing dates for yield and its components in faba bean (Vicia faba L.). Agric. Sci. Mansoura Univ., 26: 36213629.

Schill, B., A. E. Melchinger, R. K. Gumber and W. Link (1998). Comparison of intra- and interpool crosses in faba beans (Vicia faba L.). II. Genetic effects estimated from generation means in Mediterranean and German environments. Plant Breed., 117: 351-359

Soliman, A. O., T. A. Shalaby and E. M. Khalel ( 2008). Heterosis and combining ability in triploid watermelon hybrids. J. Agric. Res. Kafr-ElSkeikh Univ., 34 (3 )759-771.

Stelling, D. (1997). Heterosis and hybrid performance in topless faba beans (Vicia faba L.). Euphytica, 97:73-79
Suso, M. J. and M. T. Moreno (1999). Variation in outcrossing rate and genetic structure on six cultivars of Vicia faba L. as affected by geographic location and year. Plant Breed., 118: 347-350.

Tantawy, D. M., A. G. A. Khaled and M. H. Hosseny (2007). Genetic studies for some agronomic characters in faba bean (Vicia faba L.). Assiut J. Agric. Sci., 38 (4): 117-137.

Toker, G. (2009). Estimates of broad-sense heritability for seed yield and yield criteria in faba bean (Vicia faba L.). Hereditas, 140 (3): 222-225.

Wynne, J. C., D. A. Emery and P. W. Rice (1970). Combining ability estimates in Arachis hypogaea L. II. Field performance of $\mathrm{F}_{1}$ hybrids. Crop Sci., 10: 713-715.

تقدير قوة الهجين والقدرة على التألف في الفول البلاي بإستخدام تحليل السلالة في الكثاف

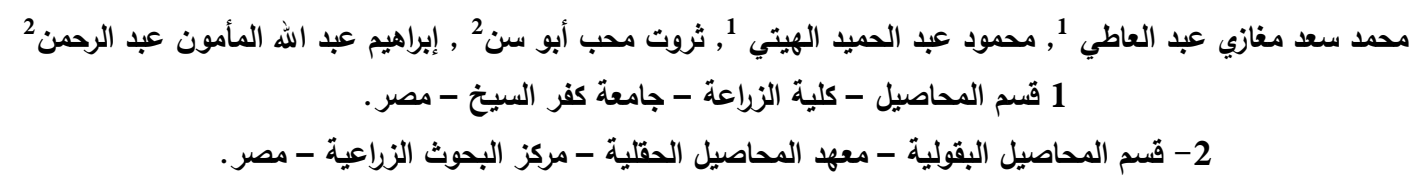

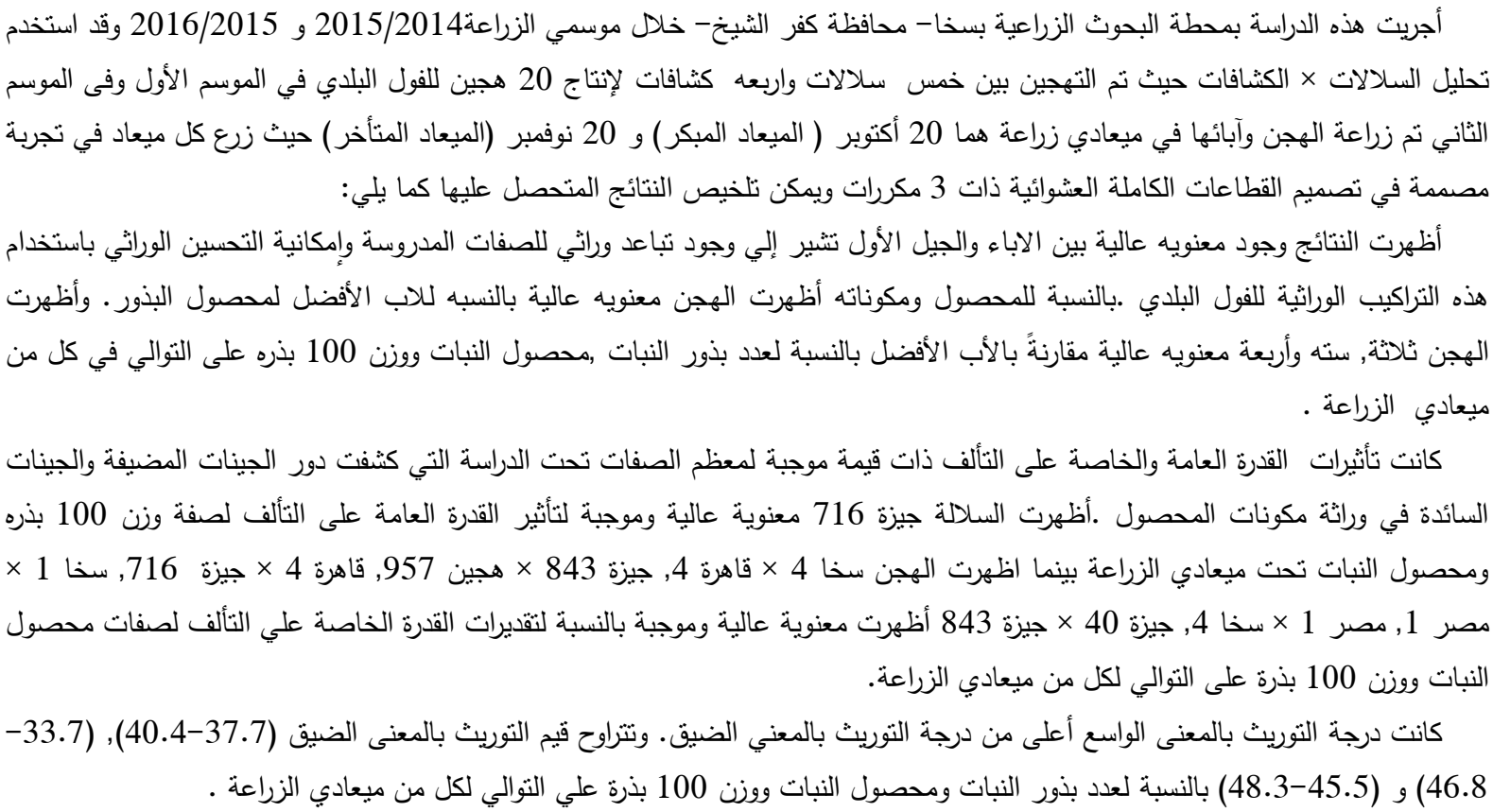


